\title{
The Influence of Obesity on Serum Insulin Measured by Three Methods
}

\author{
Atsushi ABE \\ The 1st Department of Internal Medicine, Kyoto Prefectural University of Medicine, \\ Kyoto, Japan (Director : Professor Hideo Yoshida, M.D.)
}

It has been suggested that there is close relationship between obese subjects and maturity onset diabetes from William's and Ogilvie's reports.

In the present study, this relationship between obesity and diabetes mellitus examined by determining the plasma insulin responsiveness of normal weight and obese, nondiabetic and diabetic subject to oral glucose loading. These plasma insulin were measured by three methods :the value of the rat diaphragm assay $=$ DILA, the value of the rat epididymal fat pad assay $=$ FILA, and the value of the radio-immunoassay $=$ IRI.

By comparison among these three assayed values, the investigation was undertaken to study about the effect of obesity on insulin activity.

In comparison with normal subjects, non-obese diabetics in fasting and after oral glucose loading, exhibited the low DILA, elevated FILA, slightly elevated IRI with delayed peak. It was considered that this pattern of assayed values by three methods resulted from diabetes mellitus and represented a diabetic changes. Obese diabetic subjects more definitly manifested these diabetic changes on the insulin responsiveness to glucose loading by three methods.

Despite the normal glucose tolerance, obese subjects had also diabetic changes on the insulin responsiveness by three methods.

This investigation had shown that the decrease in plasma NEFA following glucose administration was slower and smaller in obese and obese diabetic subjects than in normal subjects.

From these findings, it supposed that the high plasma NEFA levels following glucose loading gave the diabetic pattern on the insulin responsiveness by three methods.

Then for the purpose of obeserving what effects were made by the high plasma NEFA on the insulin activity by three methods, the rabbits fed high fat diet for fifty to seventy days. It noted that the high fat diet fed rabbit became obesity and had fasting high plasma NEFA concentration and disturbing the decrease of plasma NEFA following glucose loading.

The plasma of rabbit which had high NEFA concentration showed the same diabetic pattern of insulin activity by three assay methods as that of the obese human subjects.

To study the effect of NEFA on the biological insulin activity to muscle and adipose tissue in vitro, the elevated plasma NEFA were obtained from the obese rabbits following intravenous heparin injection after seventy days fed high fat diet. This elevated plasma 
NEFA exhibited the pattern of insulin activity that DILA was low, FILA was elevated and IRI was unchangeable.

From these findings, it became evident that the high NEFA concentration produced the diabetic insulin responsiveness (i.e. low DILA, elevated FILA and IRI) on plasma of the obese subjects.

Generally speaking, obesity had a normal glucose tolerance, however

1) obesity showed diabetic changes on the insulin responsiveness by three insulin assay methods,

2) obesity exhibited abnormal fat metabolism with fasting high NEFA levels and disturbing of decrease in plasma NEFA following glucose administration.

3) obesity had a insulin resistance to muscle glucose metabolism (DILA $\downarrow$ )

4) obesity demanded the increased insulin secretion from pancreatic $\beta$-cells(IRI $\uparrow$ ).

From these points obesity might become the diabetic stress and might caused one who had a family history of diabetes mellitus and fragile pancreatic $\beta$-cell, diabetes mellitus.

(pp. 1037 1055) 


\title{
三測定法による血中インスリンに及ぼす肥満の影響
}

\author{
京都府立医科大学第一内科学教室 (指導; 吉田秀雄教授)
}

阿部

敦

(昭和 43 年 3 月 10 日受付)

肥满と糖尿病の関係を追求してれより糖尿病発症の一因をさぐろうとした。インスリン三法上, 肥満 者は DILA 低く, FILA, IRI 高く糖尿病的傾向を示し, ての点成人型糖尿病のそれそ一致した。乙の 両者で空腹時 NEFA 值高く, 糖負荷後も下降が障害されているととを確認し, 糖尿病的傾向の一因を NEFA に求め, ヘパリンで高 NEFA にした家鬼血清でしれを追認した。肥満者は糖代謝は正常であ るが脂質代謝異常とインスリン抵抗性を示し，そのため過剩の IRI を膵に要求するとととなる。即ち 肥満は糖尿病的ストレスとなる。

緒 言

肥満と糖尿病，ての両者に密接な関係のあることは従来より多くの報告がある．Williams ${ }^{1)}$ は糖尿病と診 断された者の $40 \%$ は肥満しており非糖尿病者の肥満が10\%であるのに比較して有意に高頻度であると述べて いる. 更に成人型糖尿病の $80 \%$ は肥満者であつたという. 又 Joslin ${ }^{2}$ も 20 才以上の糖尿病者の 3094 人中男 63 \%女67\%が肥満であり糖尿病者中の肥満の頻度の高い事を強調している。 Ogilvie ${ }^{3)}$ は肥満が耐糖能に及ぼす 影響について，肥満の程度より肥満の持続期間と耐糖能障害の間に密接な関係のあることを報告している.

てれ等諸事実より肥満と糖尿病の間に何等かの関連のあるととを類推させる。しからば肥満は糖尿病の発 病促進因子なのか, 又糖尿病なるが故に肥満するのか諸家の議論百出する所であり著者の最も興味を感ずる 所である. Medley ${ }^{4)}$ は副腎及質ホルモンを用いた経静脈的糖負荷を肥満者に行い，肥満の程度, 持続期間, 年 令に無関係に，正常者と同じ反応をする肥満者と，もう一つ異常な反応を示す肥満者を見い出し，ての異常反 応群に糖尿病的遺伝負荷や巨大児出産の既往歴を多く有することより，肥満は糖尿病の原因でなく肥満はす でに糖尿病の素質をもつ人の発症促進因子であろうといつている. Vallance-Owen ${ }^{5)}$ は Synalbumin Antagonist の検索のもと，肥満している糖尿病者は糖尿病であるが故に肥るとのべ，Beaser ${ }^{6)}$ は simple obesity では長期にわたる追求にも糖尿病の発生頻度は増加しなかつたと報告している。

著者は肥満と糖尿病の関連性について血中インスリンの面より観察する事が重要であると考えた．肥満者 における血中インスリンは高いとの報告が多い. Karam ${ }^{7)}$ らがインスリンの免疫学的測定法により, 肥満者 に高インスリン血症のあるととを報告し，てれは糖尿病より肥満に関係があるのであろうと推論した。 てれ に対し Yalow ${ }^{8)} ら は ，$ 肥満者でブドウ糖えのインスリン反応は正常者より大きいが肥満があろうとなからう と軽症成人型糖尿病では正常者よりもつと大きなインスリン反応を示し, 高インスリン血症は肥満よりは糖 尿病本来のものであると結論している，帰する所，糖尿病発症と肥満との関係は，現在なお定説をみないの である。そこで本研究では肥満と糖尿病の関係を血中インスリン三測定法即ち，ラット横隔膜法，ラット副 辠脂法，免疫学的測定法を用いて同時に同一検体を同条件にて測定し，問題を解明しょうと試みたのである。

ラット横隔膜法は，横隔膜の glucose uptake を指標とし1939年 Gemmill ${ }^{9}$ によりはじめられ，以来 Vallance-Owen ${ }^{10)}$ 吉田 ${ }^{11)}$ ，らにより改良されたものでありてれを著者は単にインスリンの測定法としてのみ ならず，横隔膜に限らず脂肪以外の体の大部分をしめる筋組織代謝えの影響をあらわすものと考えた．ラッ 
卜副䁄脂法は1950年 Renold ${ }^{12)}$ らにより考案されたもので副䔂丸脂肪組織で $\mathrm{C}^{14}$-1-glucose より $\mathrm{C}^{14} \mathrm{O}_{2}$ 兄の 産生を指標としインスリン測定を行なうものであるがこれも血清インスリン様活性としてのみならず，脂肪 組織の糖代謝光の生物学的効果と考えた。免疫学的測定法は1960年 Berson ${ }^{13)}$ らにより報告されたものでイ ンスリンの蛋白としての抗原性に注目し抗原抗体反応という特異的な反応を利用している，以上前二者は血 清インスリンの生物学的活性を後者はインスリンの免疫学的活性を測定している. 三法にそれぞれの利点と 欠点があり，ての三者を総合的に解釈する事は肥満と糖尿病の解明に役立つものと判断した。

三測定法にて肥満と成人型糖尿病のインスリン測定を行なつた所ての両者に密接な関係を認めるに至つた. Randle $^{14)}$ らが “glucose fatty acid cycle” を発表して以来，糖尿病の脂質代謝異常が注目されて来た。 そ てで今研究では 肥满と糖尿病に共通なる変化, 即ち血中遊離脂酸の動向に着目してれの検索を実験動物を 用いておてなつた，家鬼に高脂肪食を与え，比較的短期間に肥満にし，その肥満家鬼血清のインスリン三測 定值に及ぽす影響を比較検討し，肥満人血清においてみられた糖尿病との間の密接な関係の解明の一助とし た.

説明の都合上以下二編に分けてその各々に対象，実験方法，測定法，成績をのべ括を加光，最後にまと めて考按, 総括, 結語を述べた。

\section{第 $\mathbf{1}$ 編 臨 床 的 研 究}

\section{第 I 章 対象}

\section{A) 正常対象群}

吉田内科入院患者及び研究者より, 正常対象として糖尿病的遺伝負荷のない人 22 例を選んだ.これらの人 はブドウ糖負荷試験てて, Table 1. の正常範囲であつた. Table 1. には対象を年令, 性別, 体重, $50 \mathrm{~g}$ ブ ドウ糖経口単回負荷試験（以後 GTT と略す）により 4 群に分類示した。

なお肥满度の算定は Broca index の変法：

$\frac{\text { 実測体重 } \mathrm{kg}}{(\text { 身長 } \mathrm{cm}-100)} \times 100(\%)$ を用いた.

Table 1. Classification of patients on basis of weight and carbohydrate tolerance

\begin{tabular}{|c|c|c|c|c|c|c|c|c|}
\hline \multirow{2}{*}{\multicolumn{2}{|c|}{ Group }} & \multirow[b]{2}{*}{ Cases } & \multirow[b]{2}{*}{ Age } & \multirow{2}{*}{$\begin{array}{l}\text { Sex } \\
\text { M. F. }\end{array}$} & \multirow{2}{*}{$\begin{array}{l}\text { Percent } \\
\text { of ideal } \\
\text { weight }\end{array}$} & \multicolumn{3}{|c|}{ Blood sugar response to GTT } \\
\hline & & & & & & Fasting & one & Two hr. \\
\hline A & Normal & 22 & $15-62$ & 10.12 & $90 \sim 110$ & $<130$ & $<170$ & $<130$ \\
\hline $\mathrm{B}$ & Non obese diabetic & 12 & $20-68$ & 7. 5. & $80 \sim 110$ & $85-305$ & $>180$ & $>140$ \\
\hline G & Obese diabetic & 11 & $31-65$ & 2. 9 . & $130 \sim 185$ & $90-304$ & $>180$ & $>140$ \\
\hline $\mathrm{D}$ & Obese Nondiabetic & 13 & $17-57$ & 2.11 & $130 \sim 195$ & $<130$ & $<170$ & $<130$ \\
\hline
\end{tabular}

\section{B) 非肥満糖尿病群}

Table 1. の如く糖尿病と搒断されたもので，内10例は overt diabetes，2 例は chemical diabetes であ つた. 年令, 性別, 体重は Table 1, を参照.

\section{C) 肥満糖尿病群}

糖尿病群ではいずれも未治療の吉田内科外来及び入院患者で Table 1 の如く糖尿病と診断されたもので ある. 31 才り 65才迄のいわゆる成人型糖尿病といわれるもので内 4 例は, chemical diabetes で 7 例は overt diabetes であつた.

D) 肥満非糖尿病群 
以後肥满者と略す，糖尿病の遺伝的素因のない人を当内科入院患者より選んだ。ブドウ糖負荷試験で全例 正常反応であつた。

\section{第II章 実 験 方 法}

各対象群を一脕絶食後, $50 \mathrm{~g}$ ブドウ糖経口負荷試験を行ない, 負荷前, 負荷後30分, 60分, 90分, 120分, 180分に前膊静脈より採血し，血清を分離後，血糖，インスリン及び NEFA を同時に測定した。生物学的 測定法では, 後記の理由で検体本数に制限があり, 横隔膜法では 3 点, 副睾脂法では 5 点を測定した。

\section{第III章 測 定 方 法}

\section{A) ラット横隔膜法}

Vallance-Owen ${ }^{10)}$ ，Cunningham ${ }^{15)}$ らの原法を参考代吉田 ${ }^{11)}$ ，奥村 ${ }^{16)}$ の方法に準じて多少の変法を加えた。 体重 $120 \mathrm{~g}$ 前後の Wister 系の雌性ラットを 2 週間以上室温 $20^{\circ} \mathrm{C} \pm 5{ }^{\circ} \mathrm{C}$ の恒温室においてオリエンタル固型 飼料で飼育した。一連の実験で 4 匹のラットを15時間絶食後, 断頭屠殺し速やかに横隔膜を摘出してれを 5 ${ }^{\circ}$ C以下に冷却した Gey \& Gey ${ }^{17)}$ Buffer に浸した. buffer 中にててれを4片に截断し，Fig. 1 の如くにぞ

Fig. 1. Method of distribution of qutarardiaphragm
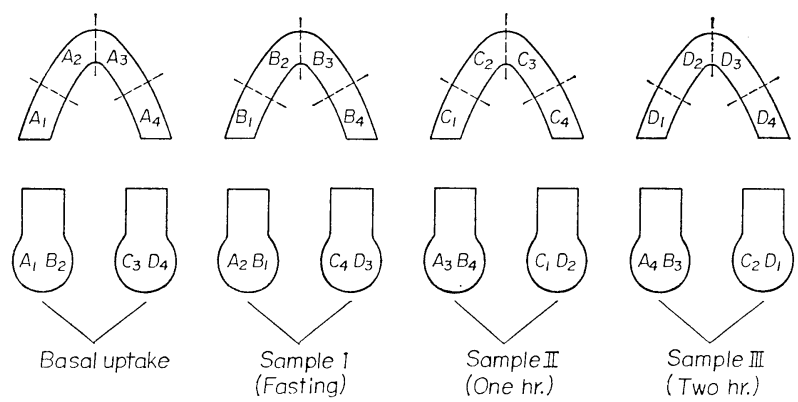

の検体も， $2 つ の$ flask の平均により算出せられ，その 2 ケの flask 中の 4 片は 4 匹のラット横隔膜の各部 分より採られておりこの操作によつてラットの個体差をいちぢるしく減じる事が出来た．各対象に GTTを 行なつた際その 3 点を, 2 重に測定する意味で 1 回の実験の 8 ケの flask の内, Fig. 1 の如く 6 ケを検体に あて残りの 2 ケを実験日の basal uptake に用いた。夏期と冬期とでは横隔膜の基礎的糖利用率に差異のあ る ${ }^{18)}$ とをを著者も認めたが，ラットを恒温空にて 2 週間以上飼育するてとによりその差を小さくする事か出 来, さらに実験当日の basal uptake を毎回測定するととにより生物学的活性に特有な季節的変動をほぼ無 視出来たものと考觉る. 予めブドウ糖 $200 \mathrm{mg} / \mathrm{d}$ lにした Gey \& Gey の incubation medium $2.0 \mathrm{ml}$ を入れ た1ケの flask 中に Fig. 1 の如く 2 片の quartardiaphragm を入れ $95 \% \mathrm{O}_{2}-5 \% \mathrm{CO}_{2}$ 混合ガスを用いて充

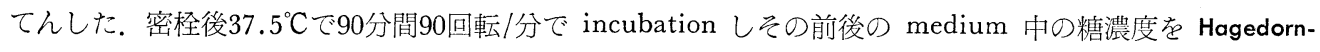
Jensen 法 $^{19}$ そより測定した. medium 中の横隔膜片は incubation 後 torsionbalanceにて科量した。横隔 膜のブドウ糖掑取量は, incubation medium 中の糖濃度の減少及び横隔膜の湿潤重量より奥村の式 ${ }^{16)}$ を以 つて算出した.

Glucose uptake $=\frac{\text { incubation 前糖濃度一incubation 後糖濃度 }}{\text { 湿 重 量 }} \times 20$

incubation medium にブドウ糖加 Gey \& Gey buffer のみを使用した場合の糖摄取量をその横隔膜の basal uptake とした，被検液を加えてブドウ糖濃度 $200 \mathrm{mg} / \mathrm{d} 1$ になるような Gey \& Gey buffer を用意し 被検液（インスリン作用濃度曲線の場合は結晶インスリン）をそれぞれに添加した場合との被検液の 
glucose uptake より同日の basal uptake を差引いた值をもつて被検液の extraglucose ( $($-uptake) 殊に その被検液にインスリン溶液点用いた場合に insulin effect とした。 insulin 濃度の $10^{-2} \mathrm{u} \sim 10^{-5} \mathrm{u} / \mathrm{ml} の$ 範囲において insulin effect をたて軸に, insulin 濃度を片対数にて横軸にとるてとによりほぼ直線関係を 有しその回帰直線は $\mathrm{Y}=0.732 \mathrm{X}-0.170$ で表わされた。 ILA 測定に際して血清を 5 倍稀釈で行ない生物学 的測定法に重要な被検液の $\mathrm{pH}$ の調整に留意した。本法により測定された血清 ILA を以後 DILA と略す。

B) ラット副睪丸脂肪組織法

Renold ${ }^{21)}$ らおよび Pfeiffer ら ${ }^{22}$ ，冨川 ${ }^{26)}$ の変法を用いた。即ち前法と全く同じ条件の雄性ラット 3 匹よ り副辠丸脂肪組織を摘出し, 各組織の末梢部を 3 分し, 総湿重量 $80 \sim 120 \mathrm{mg}$ の 3 ケの組織片を incubation medium と $\mathrm{C}^{14}$-1-glucose $(0.2 \mu \mathrm{c})$ の入つた incubation flask に入れ，95\% $\mathrm{O}_{2}-5 \% \mathrm{CO}_{2}$ 混合ガスにてガス 交換し, $37.5^{\circ} \mathrm{C} 90$ 回転/分で 3 時間 incubate する。 その後 medium に $10 \mathrm{~N}-\mathrm{H}_{2} \mathrm{SO}_{4}$, center well に $1.8 \mathrm{~N}$ $\mathrm{NaOH}$ を各々 $0.2 \mathrm{ml}$ 注入して, 更に 1 時間 incubate し, 発生した ${ }^{14} \mathrm{CO}_{2}$ を $\mathrm{NaOH}$ に吸着した。 てれ を $\mathrm{BaCl}_{2}$ と $\mathrm{NH}_{4} \mathrm{Cl}$ にて $\mathrm{Ba}^{14} \mathrm{CO}_{3}$ として沈澱させ, 乾燥して gas flow counter でその total count 測定し, self absorption を補正して counts/min./mg tissue weight を算出した。この值より insulin 濃 度 $10^{-2} \sim 10^{-6} \mathrm{u} / \mathrm{ml}$ で得られた回帰直線（ $\mathrm{Y}_{\mathrm{C}}=0.1037 \mathrm{X}+2,5066$ 両対数グラフ）を利用して ILA を $\mu \mathrm{U} / \mathrm{ml}$ として求めた。

incubation medium には glucose $300 \mathrm{mg} / \mathrm{dl}$ gelatin $200 \mathrm{mg} / \mathrm{dl}$ になる様に加えた $\mathrm{pH} 7.4$ のrebsRinger bicarbonate buffer を用いた。血清測定に際しては, incubation medium にて 5 倍に稀釈して測 定した。本法にて測定された血清 ILA をFILA と略す。

C) 免疫学的測定法

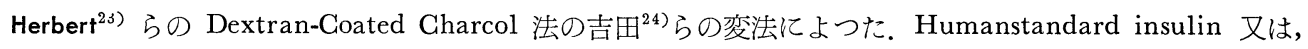
$2 \sim 10$ 倍稀釈の unknown sample $1.0 \mathrm{ml}, 2$ 万倍稀釈の Anti insulin guinea pig serum $0.5 \mathrm{ml}, 10 \mu \mathrm{U}$ の $\mathrm{I}^{131}$-insulin $0.5 \mathrm{ml}$ を $4{ }^{\circ} \mathrm{C}$ 亿て 4 日間 incubation する。 その後 $5 \%$ Charcoal と $0.5 \%$ Dextran を混和 して作成した Dextran coated charcoal を $3 \mathrm{ml}$ 添加し 3000rpm 15分間遠沈し上清と沈澱に分離しそれぞ れを count する。乙の際 AIS と結合した bound insulin は上清に, AIS と結合しない free insulin は charcoal に吸着されて沈澱する。\%Free を算出し片対数グラフにて $0.5 \sim 100 \mu \mathrm{U}$ の間にて直線を成す標 準曲線が得られた。 未知血清の\% Free より毎回作成した標準曲線を利用して未知血清の insulin 濃度を求 めた．本法により測定された血清インスリンをIRI と略す。

\section{D) 血糖測定法}

血糖測定は Hagedorn-Jensen 法 $^{19)}$ を用いた。

E) 血中遊離脂酸測定法

遊離脂肪酸（以後 NEFA と略す）は Dole 法 ${ }^{25}$ 亿よつた。

\section{第IV章 実 験 成 績}

\section{A）三測定法による各群の空腹時インスリン值}

1) DILA

Table 1 により分類した，正常者，非肥満糖尿病者，肥満糖尿病者，肥满者の 4 群の空腹時における DILA を Fig. 2 亿示した. 正常者は $210 \sim 410 \mu \mathrm{U} / \mathrm{ml}$ で平均 $320 \pm 61 \mu \mathrm{U} / \mathrm{ml}$ であつた. 非肥満糖尿病者 は 30 $250 \mu \mathrm{U} / \mathrm{ml}$ で平均 $107 \pm 60 \mu \mathrm{U} / \mathrm{ml}$ であり肥満糖尿病者では $15 \sim 220 \mu \mathrm{U} / \mathrm{ml}$ で平均 $142 \pm 66 \mu \mathrm{U} / \mathrm{ml}$ であつた．肥満者では，30〜 $300 \mu \mathrm{U} / \mathrm{ml}$ で平均 $113 \pm 45 \mu \mathrm{U} / \mathrm{ml}$ であつた. DILA は肥満, 非肥満をとわず 糖尿病者で空腹時低值を示した。未だ血桾に変化をみざる肥満においても，てれと同じく低值を示した．

\section{2) FILA}

Table 1 に従い分類した 4 群の FILA 空腹時值を Fig. 3 亿示した。正常者は 200〜650 $\mu \mathrm{U} / \mathrm{ml}$ にわたり 平均 $390 \pm 135 \mu \mathrm{U} / \mathrm{ml}$ であり非肥満糖尿病者では $300 \sim 890 \mu \mathrm{U} / \mathrm{ml}$ で平均 $529 \pm 179 \mu \mathrm{U} / \mathrm{ml}$ てあつた。肥満 
Fig. 2. Fasting insulin concentration of DILA.

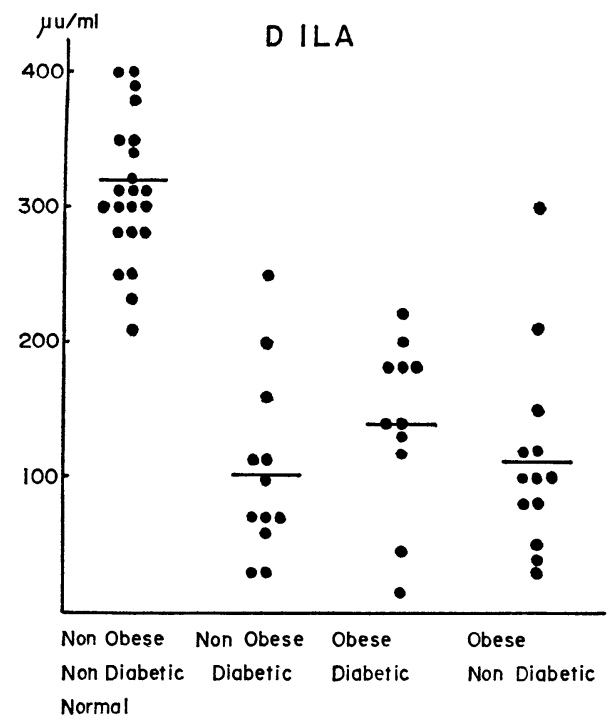

Fig. 3. Fasting insulin concentration of FILA

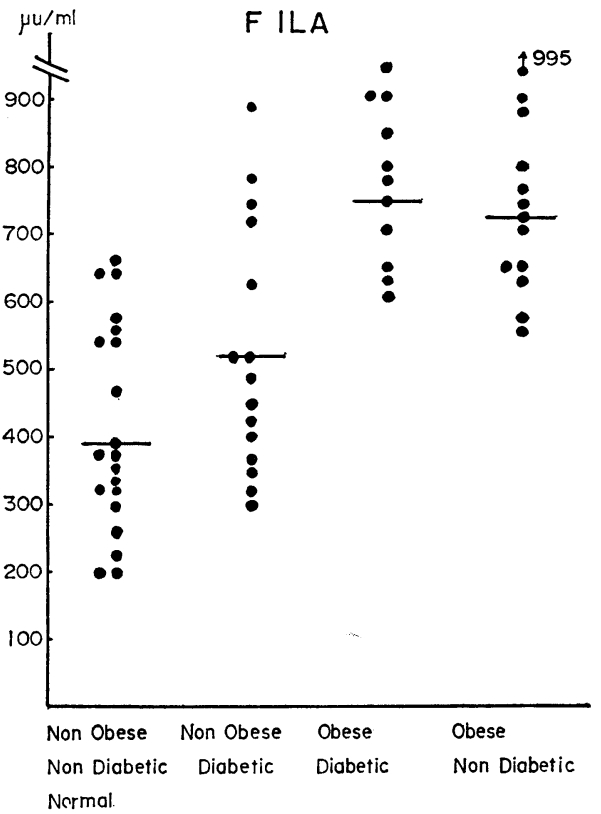

糖尿病では $605 \sim 950 \mu \mathrm{U} / \mathrm{ml}$ で平均 $766 \pm 101 \mu \mathrm{U} / \mathrm{ml}$, 肥満者では $570 \sim 995 \mu \mathrm{U} / \mathrm{ml}$ で平均 $740 \pm 118 \mu \mathrm{U} / \mathrm{ml}$ であつた。 空腹時 FILA は，非肥満でも糖尿病では正常者より高くてれに肥満をともなうとさらに高くな る. 即ち糖疗病者で FILA は高くなる，肥満者で も糖尿病と同じく正常者より有意に高い.

Fig. 4. Fasting insulin concentration of IRI

\section{3) IRI}

4 群の空腹時 IRI を Fig. 4 に示した. 正常者は $10 \sim 40 \mu \mathrm{U} / \mathrm{ml}$ で平均 $18 \pm 5 \mu \mathrm{U} / \mathrm{ml}$ であつた. 糖尿 病の非肥満は $15 \sim 46 \mu \mathrm{U} / \mathrm{ml}$ で平均 $25 \pm 8 \mu \mathrm{U} / \mathrm{ml}$ で，肥満は 38〜 $70 \mu \mathrm{U} / \mathrm{ml}$ で平均 $52 \pm 11 \mu \mathrm{U} / \mathrm{ml}$ で あつた．肥満非糖尿病者は $30 \sim 84 \mu \mathrm{U} / \mathrm{ml}$ で平均 $55 \pm 7 \mu \mathrm{U} / \mathrm{ml}$ である. 空腹時 IRI は非肥満糖尿病 で正常者より若干高く, 肥満糖尿病になると有意に 高值を示した。 即ち空腹時 IRI は糖尿病で正常者 より若干高く, 肥満では有意に高值を示した。

以上 1）2）3）をまとめると非肥満糖尿病で正 常者に比較して DILA 低く, FILA 高く, IRI が 若干高い傾向を示し, 肥満糖尿病になればこの傾向 はさらに強くなつた. 非糖㽷病でも肥満にはこの傾 向がみられる。

\section{B） 三測定法による糖負荷時の血糖及びインスリ ン変動}

1）正常対象群

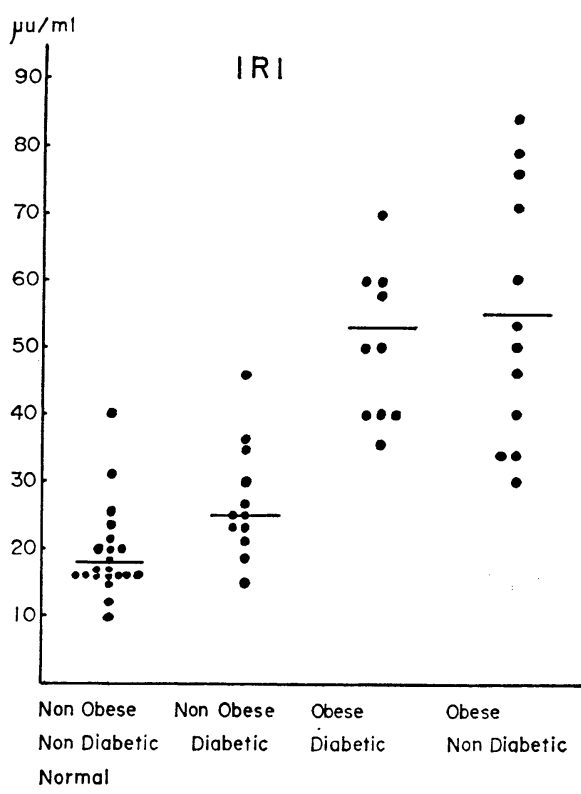


正常者の糖負荷後の 血糖曲線 を Fig. 5 亿示した. 前, 30 分, 60 分, 90 分, 120 分, 180 分の血糖值は各 々 $83 \pm 10,132 \pm 21,131 \pm 13,109 \pm 8,90 \pm 11$, $75 \pm 14 \mathrm{mg} / \mathrm{dl}$ であつた. 正常者の糖負荷後の DILA, FILA，IRI の変動を Fig. 6 亿示した. DILA は 前, 60分, 120 分で各々 $320 \pm 61,503 \pm 130,380 \pm$ $106 \mu \mathrm{U} / \mathrm{ml}$ であつた，前，30分， 60 分， 90 分， 120 分の FILA は各々 $390 \pm 135,448 \pm 150,672 \pm 170$, $457 \pm 130,365 \pm 79 \mu \mathrm{U} / \mathrm{ml}$ であり IRI は $18 \pm 5$, $61 \pm 15,70 \pm 13,61 \pm 8,47 \pm 8 \mu \mathrm{U} / \mathrm{ml}$ であつた. 血 糖曲線は30分で頂値に達し，三測定法による ILA， IRI は60分で頂值になつた．Fig. 6 の三つの曲線は その単位てそ違うが，ほぼ同じ型を示し，糖負荷後 の血清インスリンの変動をそれぞれの面で把握して いるものと判断した。
Fig. 5. Blood sugar during GTT in normal subjects.

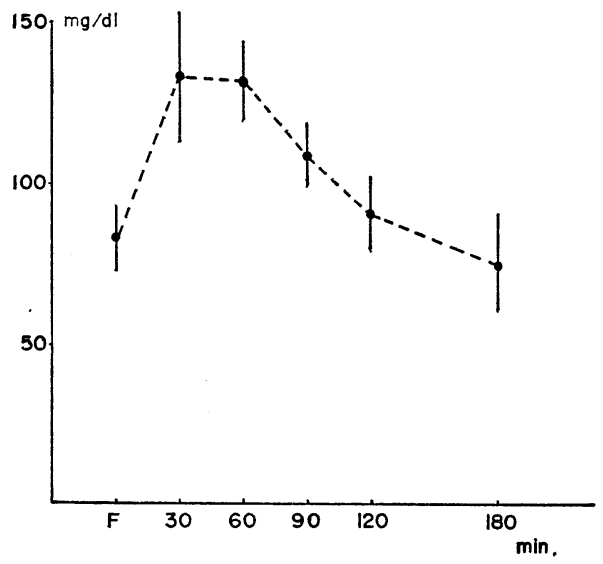

Fig. 6. Serum insulin response during GTT in normal subjects.

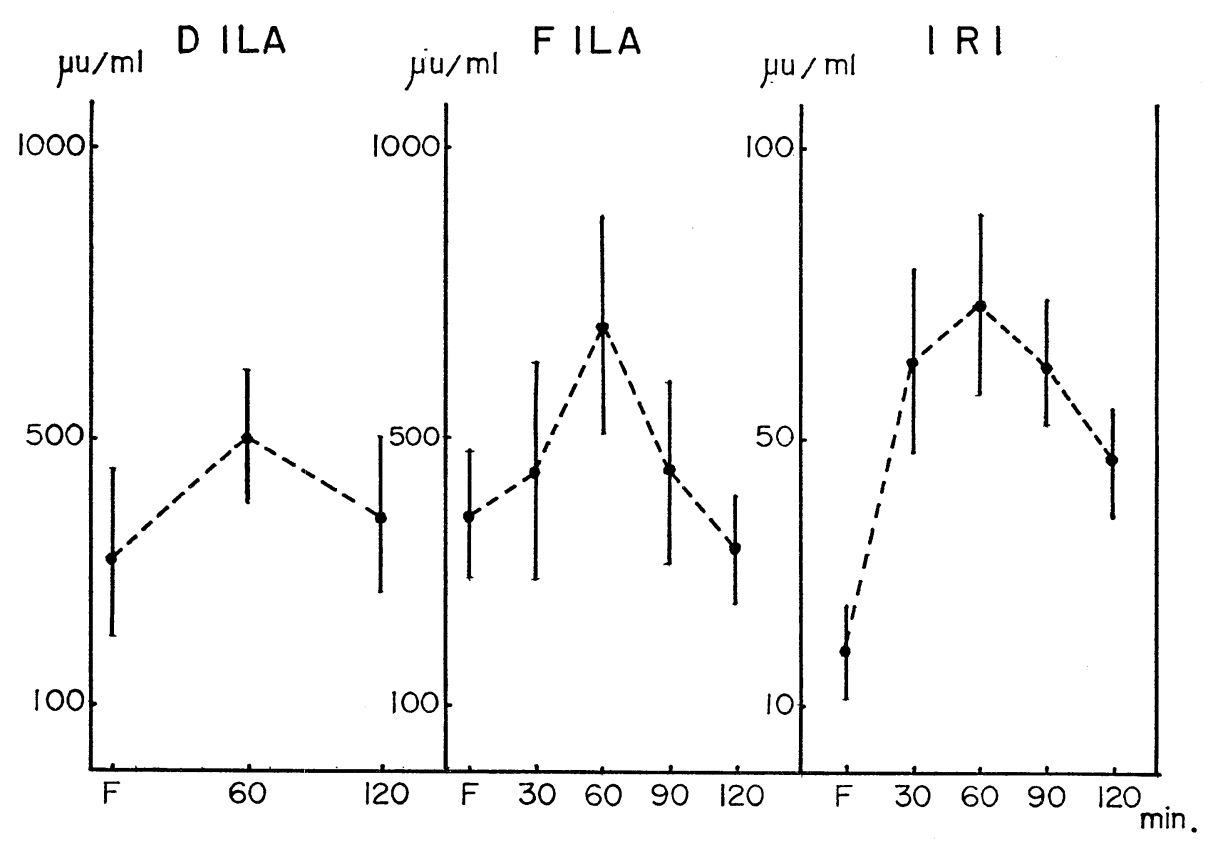

\section{2) 非肥満糖尿病群}

Fig. 7 亿非肥満糖尿病者の糖負荷後の血糖曲線を描いた。血糖値は各々 $205 \pm 30 ， 290 \pm 52 ， 329 \pm 45 ， 317$ $\pm 54,314 \pm 57,270 \pm 52 \mathrm{mg} / \mathrm{dl}$ であつた，点線の正常者に比べ空腹時高く負荷後も高值を維持した。糖負荷

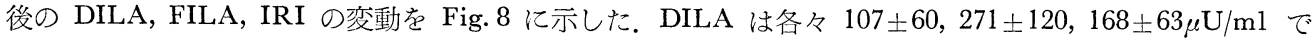
あつた。 FILA は各々 $522 \pm 179,704 \pm 147,818 \pm 131,765 \pm 174,704 \pm 126 \mu \mathrm{U} / \mathrm{ml}$ で IRI は $25 \pm 8,52 \pm 17$, $70 \pm 16,85 \pm 10,80 \pm 7 \mu \mathrm{U} / \mathrm{ml}$ であつた. 点線の正常者に比較して DILA は低く FILA は高かつた. IRI は前值やや高く頂值が90分に遅延しさらに高值を持続していた。 即ちてれが肥満の影響をうけない三法測定 
Fig. 7. Blood sugar during GTT in non obese, diabetic subjects.

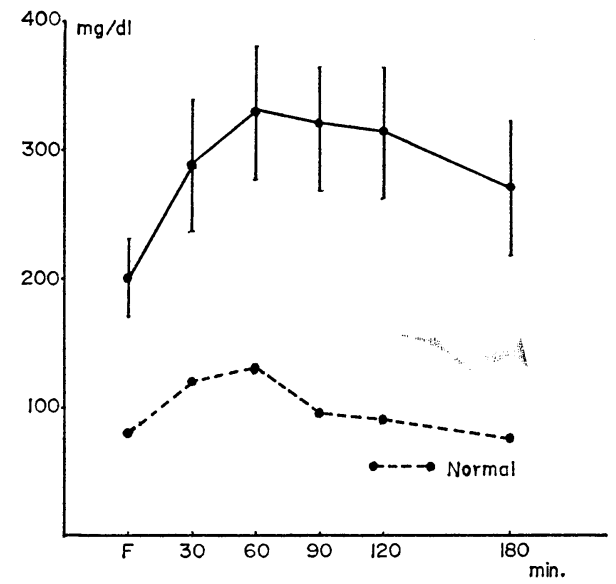

Fig. 8. Serum insulin response during GTT in non obese, diabetic subjects.

D ILA

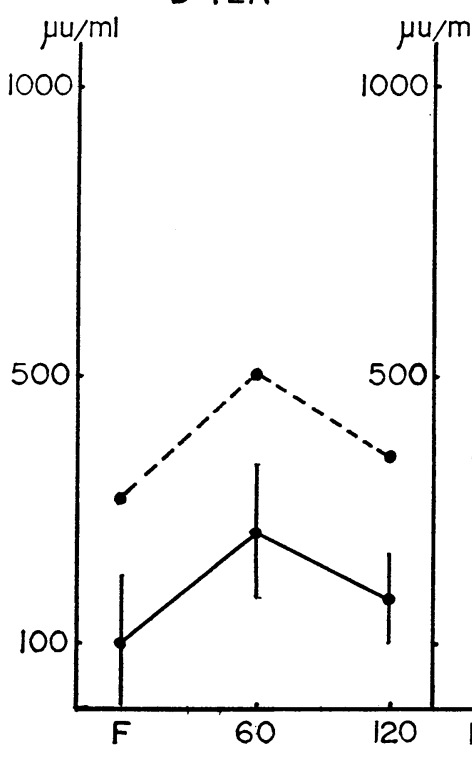

\section{F I LA}

$|R|$

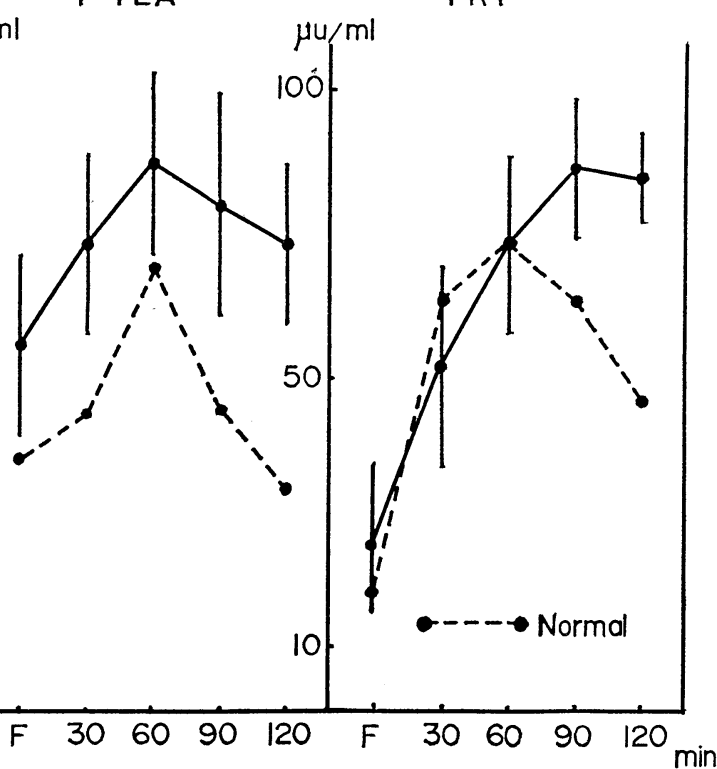

上の糖尿病的傾向である.

\section{3) 肥満糖尿病群}

Fig. 9 は糖負荷後の血糖曲線である．血糖值は各々 $181 \pm 40 ， 271 \pm 45 ， 313 \pm 62 ， 309 \pm 36 ， 260 \pm 25$, $235 \pm 26 \mathrm{mg} / \mathrm{dl}$ であり点線の正常者に比較して, 空腹時高く以後, 高值を持続した. Fig. 7 の非肥満糖尿病 群の血糖曲線と比較する時, 空腹時やや低值を示す以外負荷後はかわらない. 即ち両糖尿病群は血糖上糖尿 病重症度に差がなかつた。糖負荷後の DILA, FILA，IRI の変動を Fig.10 亿示した。 DILA は各々 
Fig. 9. Blood sugar during GTT in obese, diabetic subjects.

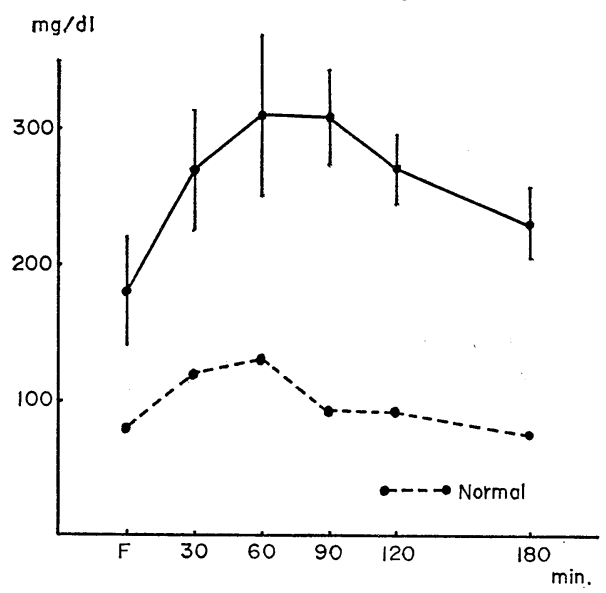

Fig. 10. Serum insulin response during GTT in obese diabetic subjects.

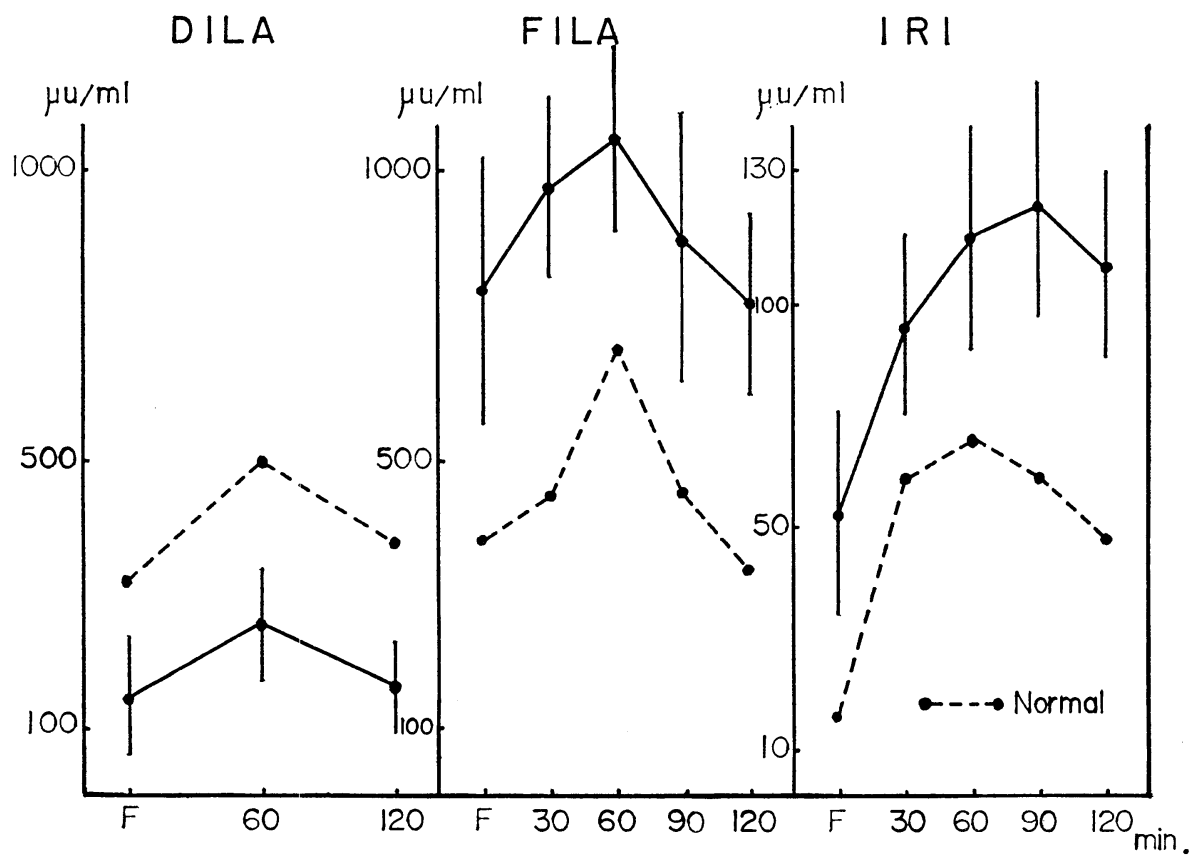

$142 \pm 66,248 \pm 92,161 \pm 70 \mu \mathrm{U} / \mathrm{ml}$ であつた. FILA は 766 $101,911 \pm 140,1053 \pm 160,1030 \pm 20,743 \pm 150$. IRI は $52 \pm 11,95 \pm 19,115 \pm 25,122 \pm 28,107 \pm 22 \mu \mathrm{U} / \mathrm{ml}$ であつた. 点線の正常群に比較して DILA は 低くFILA は高かくIRI も空腹時すでに高く負荷後も過剩反応及び頂值遅延を呈した。 Fig. 8 の非肥満糖 尿病者に比較すると先に述べた三法上の糖尿病的傾向が更に著明になつている.

4) 肥満非糖尿病群

Fig. 11 は肥満者の血糖曲線である。血糖值は各々 $88 \pm 8,140 \pm 10,142 \pm 23,132 \pm 20,102 \pm 20,87 \pm$ 第44巻:第 9 号 
I4mg/dlであり点線の正常群に比較して30分，60分，90分で僅かに高いが Table 1 の基準によれば正常な 耐糖能である。 GTT 中の三法測定值をFig. 12 亿示した。 DILA は各々 $113 \pm 45,310 \pm 140,207 \pm 103 \mu \mathrm{U} / \mathrm{ml}$ で, FILA は $740 \pm 118,2195 \pm 366,2127 \pm 436,1530 \pm 330,1455 \pm 359 \mu \mathrm{U} / \mathrm{ml}$ で IRI は $55 \pm 7,81 \pm 31$, $153 \pm 45,150 \pm 31,98 \pm 30 \mu \mathrm{U} / \mathrm{ml}$ であつた. 点線の正常群と比較すると DILA で低く FILA, IRI 高く, 未だ耐糖能正常なる肥満ですでに三測定法上糖尿病的傾向を示した (Fig. 8 と Fig. 10 を参照).

Fig. 11. Blood sugar during GTT in obese, non diabetic subjects.

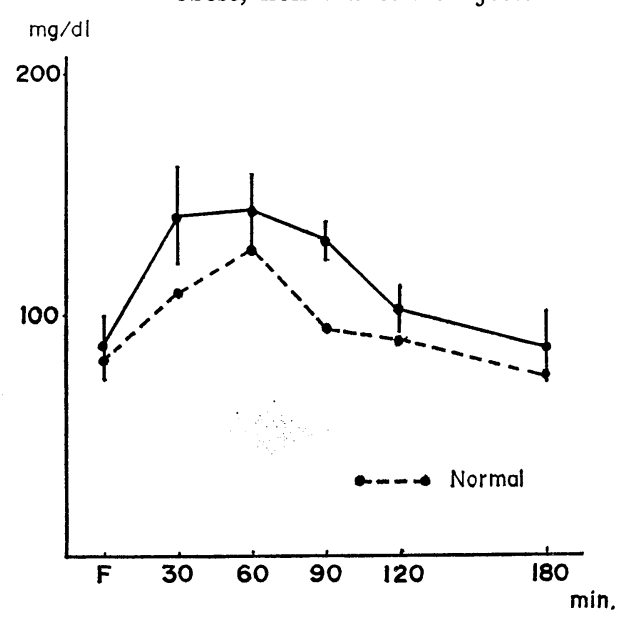

Fig. 12. Serum insulin response during GTT in obese, non diabetic subjects.

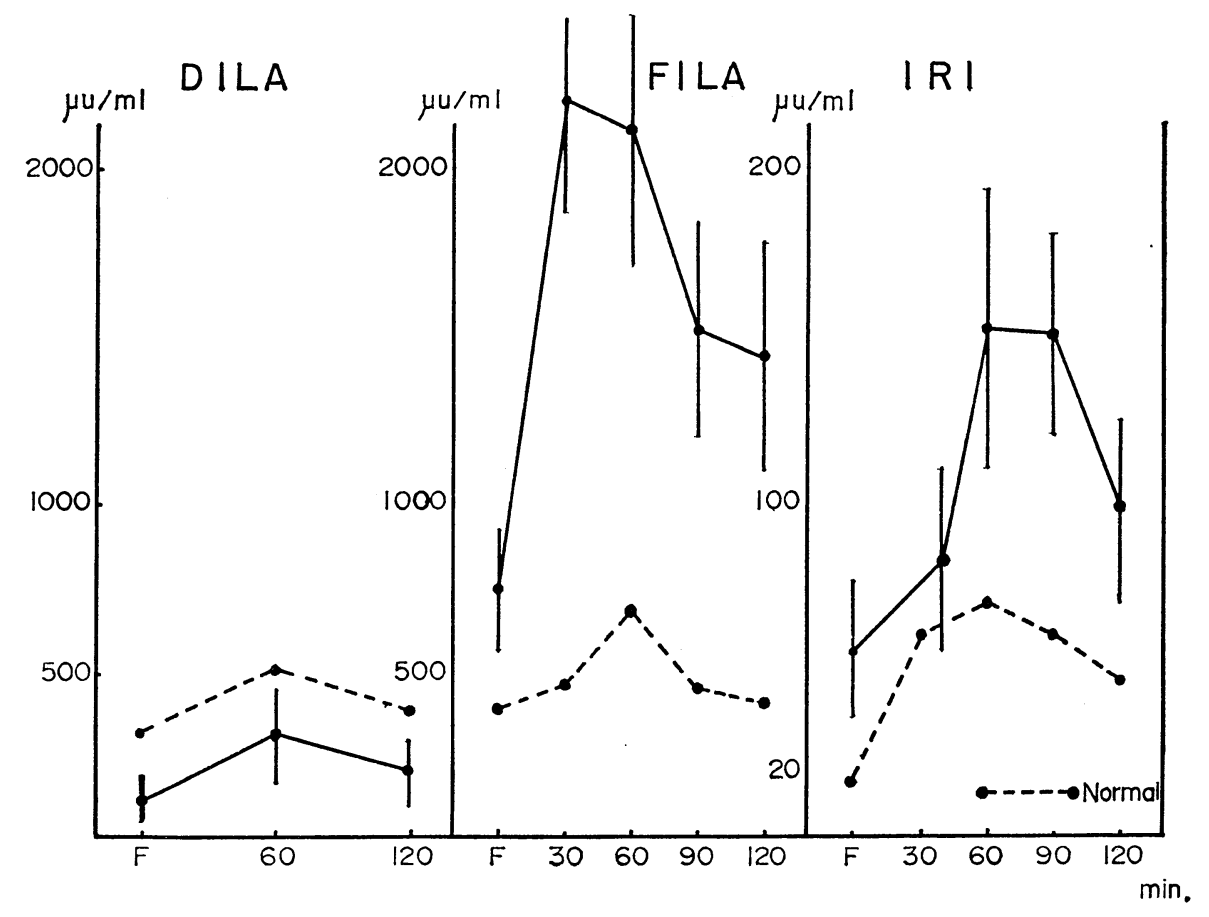




\section{C) 糖負荷時の血中 NEFA 变動}

正常者, 肥満糖尿病群, 肥満群の三者に $50 \mathrm{~g}$ 糖負荷を行ないその血糖及び NEFA 変動を Fig. 13 に示し た，各群 5 例の平均である. 正常者の血糖は $84 \pm 21,130 \pm 21,154 \pm 14,132 \pm 13,110 \pm 10,86 \pm 11 \mathrm{mg} / \mathrm{dl}$

Fig. 13. Blood sugar and NEFA levels to GTT in normal \& obese non diabetic, diabetic subjects.

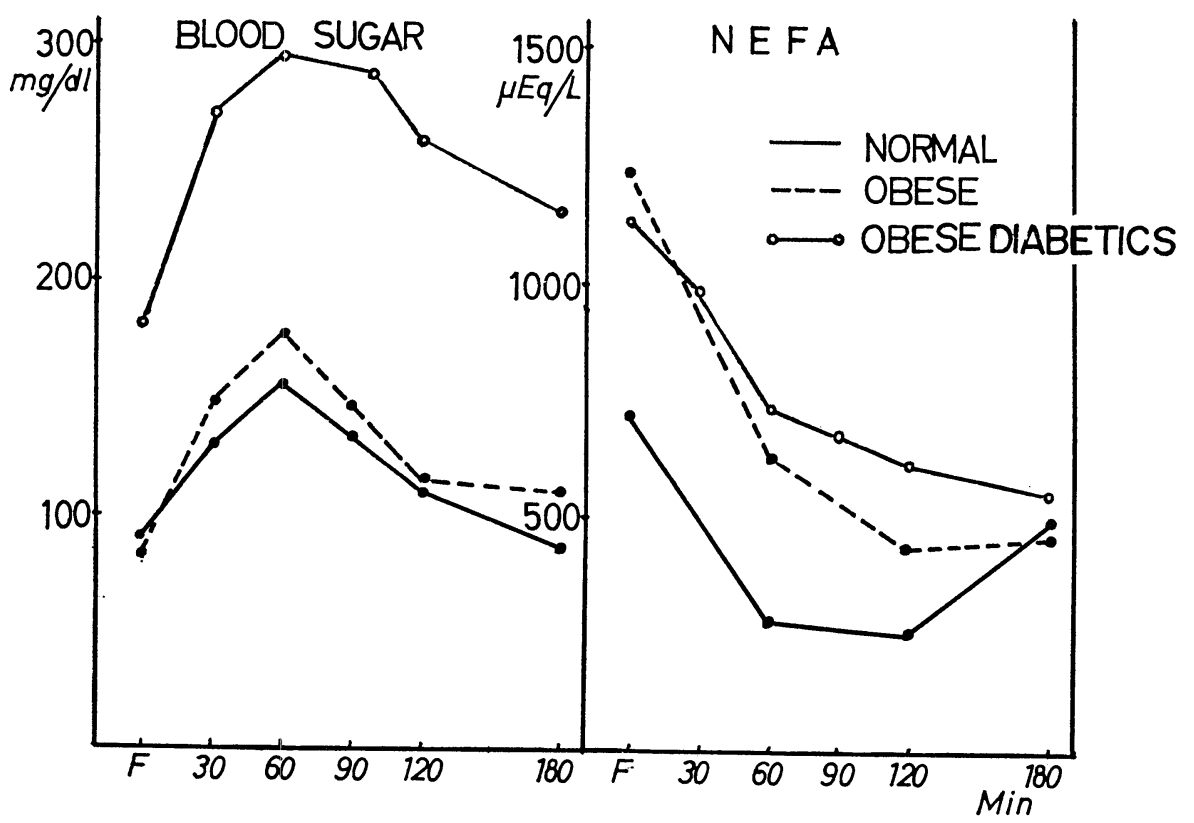

肥満糖尿病では $180 \pm 30,270 \pm 43,294 \pm 40,288 \pm 47,260 \pm 5,230 \pm 50 \mathrm{mg} / \mathrm{dl}$ 肥満では $82 \pm 25,148 \pm 23$, $168 \pm 20,146 \pm 21,116 \pm 25,110 \pm 18 \mathrm{mg} / \mathrm{dl}$ であつた. Table 1 により肥満者の血糖反応は正常である. 次に正常者の NEFA は前, 60分, 120分, 180 分で各々 $720 \pm 210,270 \pm 105,240 \pm 98,490 \pm 110 \mu \mathrm{Eq} / \mathrm{L}$ で 肥満糖尿病で前, 30 分， 60 分， 120 分，180分で $1130 \pm 320,990 \pm 219,730 \pm 185,680 \pm 152,610 \pm 132,550 \pm$ $140 \mu \mathrm{Eq} / \mathrm{L}$, 肥満者で前, 60 分, 120 分, 180 分で $1240 \pm 230,630 \pm 180,440 \pm 108,450 \pm 95 \mu \mathrm{Eq} / \mathrm{L}$ であつた. 正常者に比較して肥満糖尿病及び肥満者で NEFA 值は空腹時すでに高く, GTT 後も下降が障害されて いる点が共通している。

\section{第 $\mathrm{V}$ 章 本 編 小 括}

以上四群に糖負荷を行ない, 血糖, DILA, FILA, IRI, NEFA の測定値を述べた。両糖尿病群において は DILA 低く FILA 高くIRI 高く頂值遅延の糖尿病的傾向を示したが, 未だ GTT 上正常である肥满 者においてもこれと類似の傾向をみた. 更に GTT 後の NEFA 変動を検索するに肥満糖尿病者及び肥満 者は同様な NEFA の変動を示したので, 糖尿病と肥满の関係を NEFA の変動に求め, 次の実験を計画実 行した.

\section{第 2 編 実 験 的 研 究}

\section{第 I 章 実験材料及び実験方法}

体重 2.3 3.0 kg 平均 $2.6 \mathrm{~kg}$ の成熟雌性家鬼10匹を用いた。処置前対象として, 15時間の絶食後, $\mathrm{kg}$ あた 
り $0.5 \mathrm{~g}$ のブドウ糖を耳静脈より注射し，前, 15分, 30分で他方の耳静脈より採血した。採血後直ちに遠沈分離 し測定に供した。なお DILA, FILA，IRI，NEFA は空腹時と30分值のみを測定した。 GTT 後30分を測定 亿選んだのは富川 ${ }^{26)}$ ，野田 ${ }^{27)}$ ，の報告より NEFA 值と ILA 值の間の差が最大になる時間を選んだためで ある. 又測定頻度が少ないのは一回の測定に血液約 $15 \mathrm{ml}$ 要するので頻回の採血を不能としたためである. 処置前対象として採血後オリエンタル社作成の成分 Table 2 の高脂肪食飼料を70日間与えた。 50 日目及び

Table 2. Composition of diet

\begin{tabular}{c|l|c|c}
\hline & & Normal diet & High fat diet \\
\hline \hline 1 & Protein & $22.8 \%$ & $23.1 \%$ \\
2 & Fat & $4.8 \%$ & $10.2 \% *$ \\
3 & Carbohydrate & $46.2 \%$ & $43.2 \%$ \\
4 & Vitamin, etc & $26.2 \%$ & $23.5 \%$ \\
\hline
\end{tabular}

* This high fat diet was made by adding a largest amount of tallow which do not permit rabbit to become diarrhoea.

70 日目に家鬼を絶食後 $\mathrm{kg}$ あたり $0.5 \mathrm{~g}$ のブドウ糖静注負荷を行ない, 空腹時と 30 分後に採血を行ない, NEFA, DILA，FILA，IRI の測定に供した。なお70日目の高脂肪食家鬼 5 匹に，ノボ社のヘパリン $2000 U$ (500U/ kg）を静注し，30分後に採血 NEFA，DILA，FILA，IRI を測定した.

\section{第II章 測 定 方 法}

第 1 章と同じ測定法を用いた.

\section{第III章 実 験 成 績}

\section{1) 体重, 血糖及び NEFA}

Fig. 14 亿体重の推移とその時の空腹時血糖值と NEFA 值を示した. 体重は Table 2 の高脂肪食を 与えてから50日に $3.7 \mathrm{~kg} ， 70$ 日に $4.0 \mathrm{~kg}$ となつた。 在来雑種雌性家鬼では $3.0 \mathrm{~kg}$ 前後で普通飼料の場合, 体重がほぼ一定する。高脂肪食を70日間投与して $3.7 \sim 4.0 \mathrm{~kg}$ 亿なつたのを一応肥満と考えた. Fig. 14 の実線は空腹時の血糖の推移であるが処置前，50日， 70 日で各々 $115 \pm 23,106 \pm 22,111 \pm 15 \mathrm{mg} / \mathrm{dl}$ と著 変なく, NEFA は各々 $513 \pm 95,702 \pm 104,642 \pm$ $81 \mu \mathrm{Eq} / \mathrm{L}$ で50日に最も高い値を示し，70日ではや や低值を示した，各時期に GTT を行ないその血 糖と NEFA 変動を Fig. 15 亿示した. 実線は血糖 值で処置前各々 $115 \pm 23,200 \pm 20,192 \pm 23 \mathrm{mg} / \mathrm{dl}$ 50 日で $106 \pm 22,192 \pm 15,181 \pm 40 \mathrm{mg} / \mathrm{dl}, 70$ 日で $111 \pm 15, \quad 185 \pm 21 ， 177 \pm 42 \mathrm{mg} / \mathrm{dl}$ であつた. 高脂 肪食により体重増加を来した家鬼の空腹時血糖及び 酎糖能には著変をみなかつた。一方点線は NEFA 变動で，処圆前各々 $513 \pm 95 ， 324 \pm 72 ， 50$ 日は 702
Fig. 14. Changes in body weight, fasting blood sugar and fasting NEFA concentration of high fat diet rabbits.

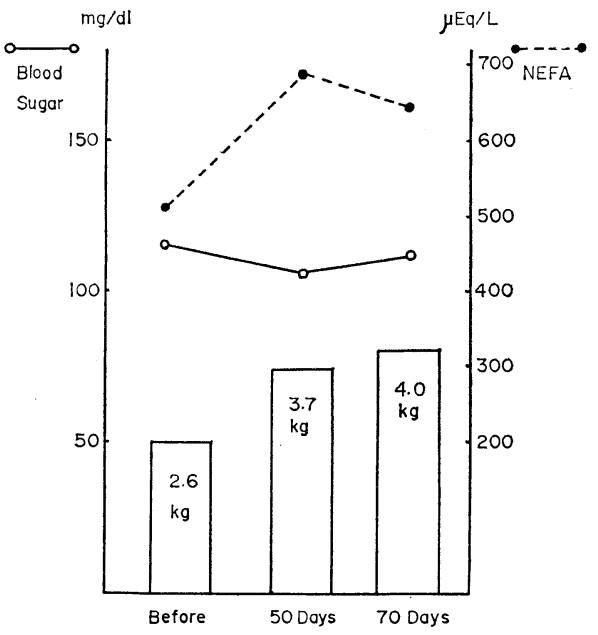


Fig. 15. Blood sugar and NEFA levels during GTT at each stage.

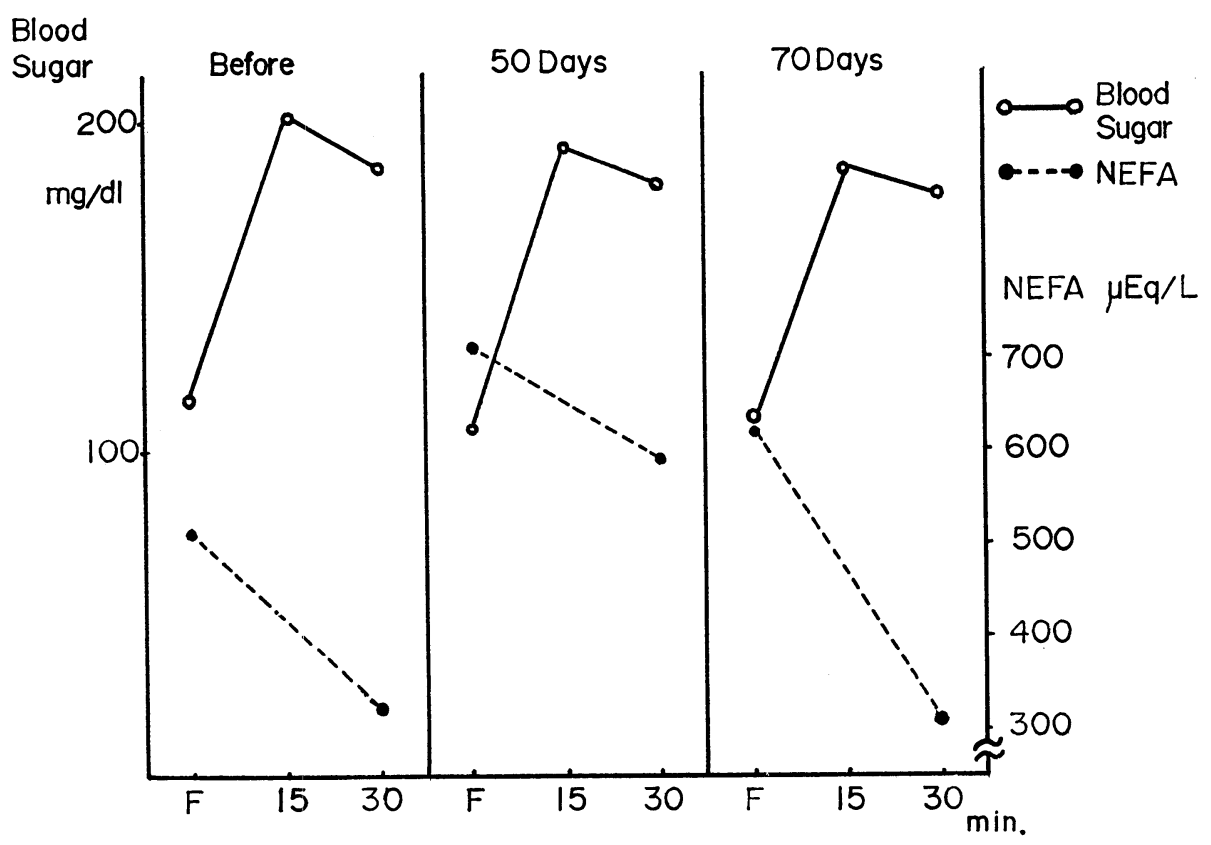

$\pm 104 ， 580 \pm 48 ， 70$ 日で $642 \pm 81 ， 305 \pm 97 \mu \mathrm{Eq} / \mathrm{L}$ となつた．NEFA は処置前に比較すると50日で空腹時 すでに高值を示し, 糖負荷後も下降が有意に障害されている。70日も空腹時高いが負荷後はよく下降した. NEFA の糖負荷後の下降をもつて脂質代謝の一面をみているとすれば，50日時にもつともそれが障害され ていた.

\section{2 ）高脂肪食肥満家鬼の三法に及ぼす影響}

次に各時期における DILA，FILA，IRI を Fig. 16 亿示した。 DILA は処置前 $330 \pm 129 ， 680 \pm 374$, 50 日で $176 \pm 40,607 \pm 324,70$ 日で $210 \pm 64,610 \pm 374 \mu \mathrm{U} / \mathrm{ml}$ で50日時空腹時最も低く, NEFA の高い時期 と一致した。70日時も空腹時やや低い值を示した。 FILA は処置前 $370 \pm 102,730 \pm 346,50$ 日で $720 \pm 178$, $1100 \pm 222 ， 70$ 日で $660 \pm 300 ， 1850 \pm 469 \mu \mathrm{U} / \mathrm{ml}$ となつた．処置前に比較して，50日に空腹時既に著明な 高值を示し負荷後も高く NEFA の高值と一致した． IRI は処置前 $10 \pm 3,40 \pm 19 \mu \mathrm{U} / \mathrm{ml} ， 50$ 日で $28 \pm 5$, $51 \pm 12 \mu \mathrm{U} / \mathrm{ml}, 70$ 日で $28 \pm 7,58 \pm 9 \mu \mathrm{U} / \mathrm{ml}$ となつた，処置前と比較するとき50日と70日時には空腹時既に 高值を示し負荷後やや過剩反応を呈した.

\section{3 ）ヘパリン静注による高 NEFA 值の三法に及ばす影響}

70 日時の平均 $4.0 \mathrm{~kg}$ の高脂肪食家鬼 5 匹に，15時間絶食後耳静脈より，ヘパリン $\mathrm{kg}$ あたり500U を静注し 30分後に他方耳静脈より採血した。静注前と30分後の血糖と NEFA 值, DILA, FILA, IRI を Fig. 17 亿 示した。血糖值は $112 \pm 15$ から $121 \pm 25 \mathrm{mg} / \mathrm{dl}$ と著変なく, NEFA は $642 \pm 81$ から $1469 \pm 400 \mu \mathrm{Eq} / \mathrm{L}$ と著增し ている. DILA は $210 \pm 72$ から $48 \pm 38 \mu \mathrm{U} / \mathrm{ml}$ と減少し, FILA は $660 \pm 278$ より $1890 \pm 642 \mu \mathrm{U} / \mathrm{ml}$ と急増 し, IRI は $28 \pm 9$ から $30 \pm 6 \mu \mathrm{U} / \mathrm{ml}$ と変らなかつた。

\section{第IV章 本 編 小 括}

成熟家鬼に高脂肪食を与え体重を増加せしめ血中 NEFA を in vitro で比較的生理的に上昇させ，人に おける肥満と比べた，50日より70日にわたる高脂肪食家鬼には糖負荷による耐糖能の変化はみられなかつた。 
Fig. 16. Serum insulin response during GTT in high fat diet rabbits at each stage.

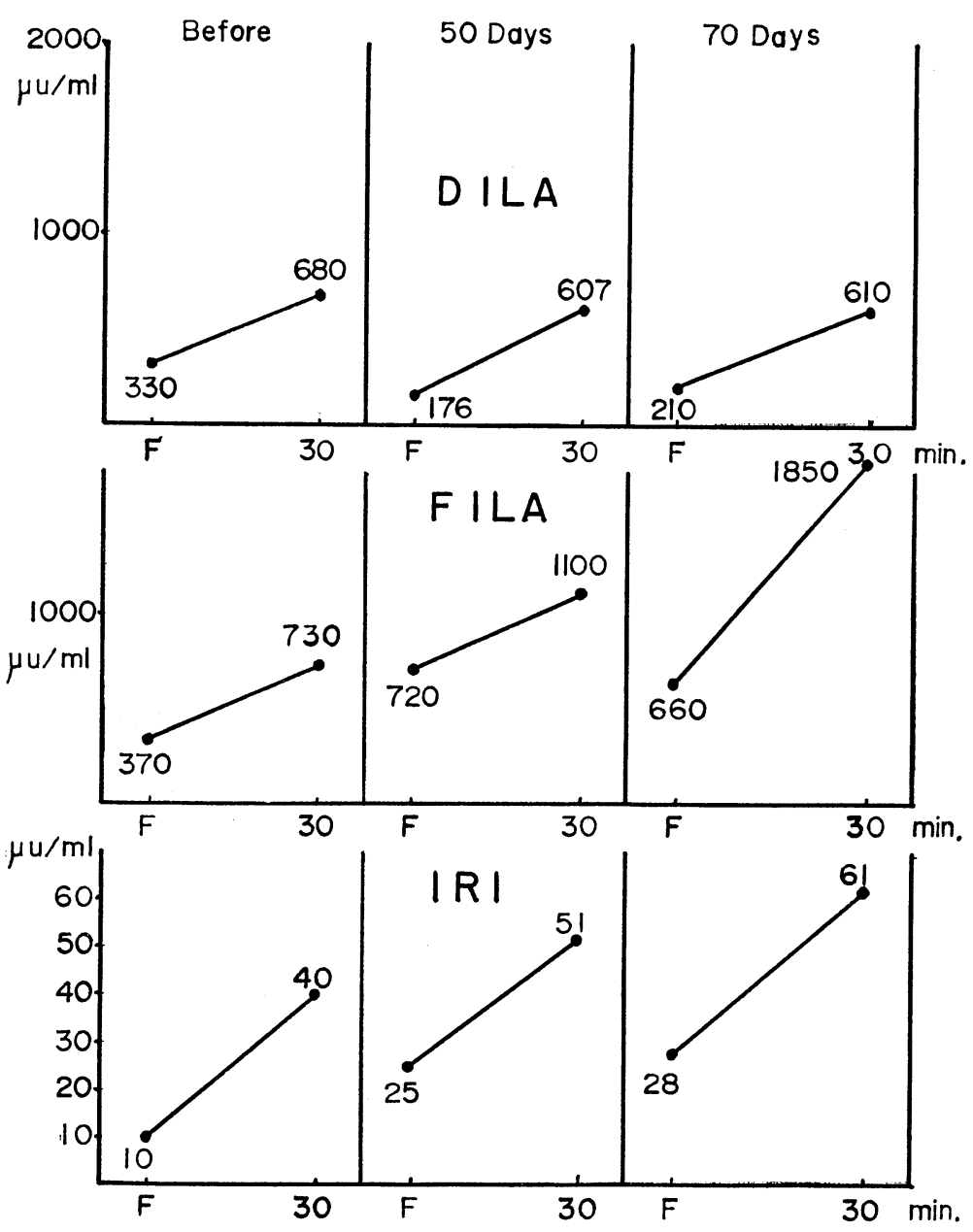

一方血中 NEFA は50日時，最も高い值を示し負荷後も下降が障害されていた．70日時では前値は高かつた が，糖負荷後はよく下降した．三測定法にての高脂肪食家鬼血清の与える影響は興味深い. 即ち50日で空腹 時 DILA 低く FILA, IRI 高い人肥満血清と類似の傾向をみると共に，70日 $4.0 \mathrm{~kg}$ 前後の家鬼で糖負荷後 FILA，IRI で過剩反応を呈してれも同様の反応を示した。 in vitro で NEFA 添加の代りに高脂肪食肥満 家鬼にヘパリンを注射して NEFA を高值にし，乙れの三法に与える影響をみた。 IRI 不変にもかかわら ず，DILA 低く，FILA は高い值を示し，NEFA が生物学的インスリン活性に与える影響を確認した。

\section{全 編 考 按}

肥満と糖㽷病, 特に成人型糖尿病との間には何等かの因果関係があり, てれを追求する事が, 糖尿病発症 の一因をさぐる事になろう。今日迄肥満の糖代謝に及ぼす影響について幾多の報告がある ${ }^{2829)}$. Newburg ${ }^{30)}$ は肥満型糖尿病患者の体重を減少させることにより耐糖能を改善したとのべ, Faludi ${ }^{31)} は$, 肥満は糖尿 病発症の “predisposing factor” であるばかりでなく，早期糖尿病に惹起せられる insulin 分泌の機能的障 
Fig. 17. Ghanges of blood sugar, NEFA concentration and insulin levels by three methods following heparin intravenous injection at 70days.

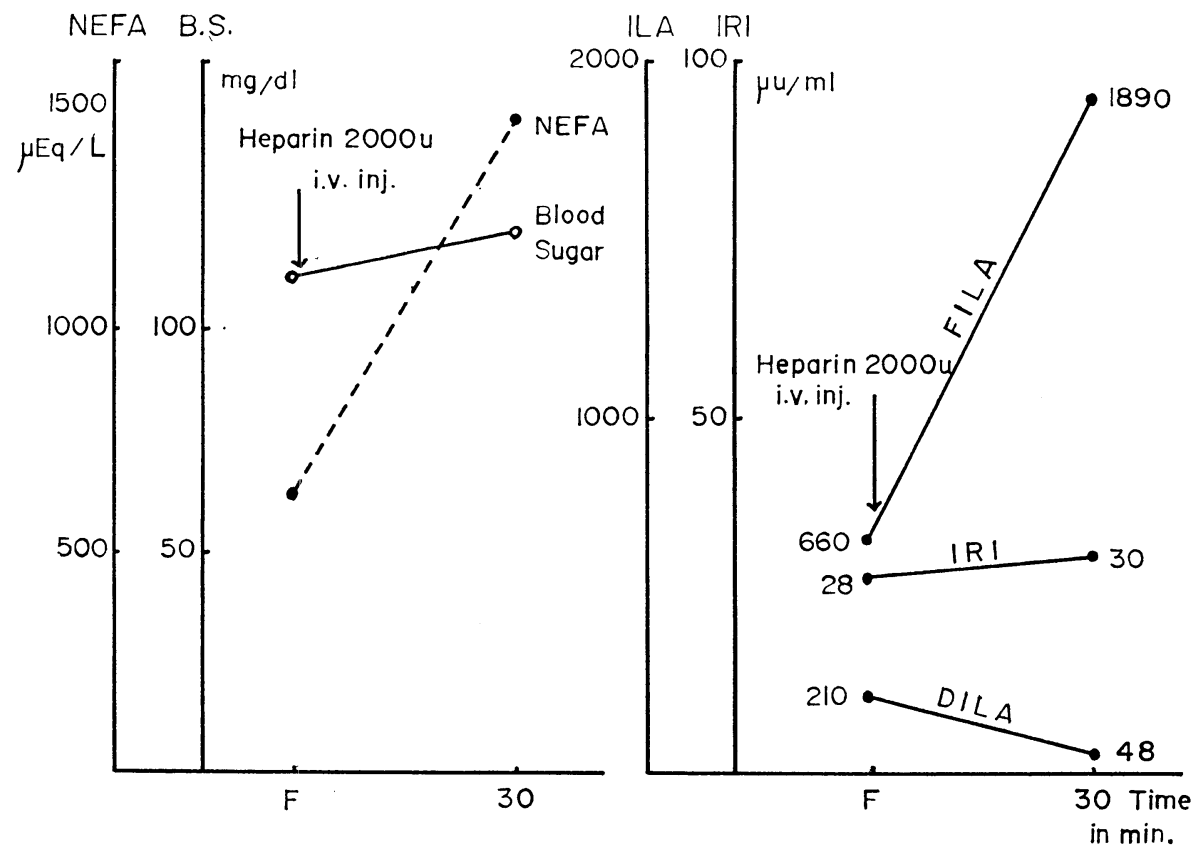

害により，肥満がもたらされるとのべている。 Rabinowitz らは ${ }^{32)}$, 前膊の筋及び皮下脂肪組織のブドウ糖と NEFA の摂取より, 肥満には, insulin resistance があり, 肥満は糖尿病の先駆症状として関係があるとし ている。乙れら諸研究は肥満と糖尿病発症との関連を類推させるが，なおその因果関係を説明するに十分で なく，近年開発されて来た，血中インスリン測定の面より考察する必要性を認めた.

Bornstein $^{33)} ら か ゙$ in vivo の生物学的測定法を用い成人型糖尿病で血中インスリンが正常者に比較して低 い事を, Vallance-Owen ${ }^{34)}$ はラット横隔膜法を用いて肥満糖尿病で正常者と比べてかわらなかつたと報じ, 奥村 ${ }^{16)}$ は同法をもちいて, 糖尿病の ILA が正常者に比較して低值を示したと報告している.ラット副童脂 法を用いて, Samaan ら ${ }^{35)}$ は肥満者で typical ILA と atypical ILA の両者共正常者より高く, 後者が血 中 NEFA に関係があるとのべている。同じ副箤脂法で, Daweke ${ }^{36)}$ らや Bottermann ${ }^{37)}$ も空腹時及び糖負荷 後肥満者で FILA の高值を確認している，免疫学的測定法でも，肥満者で空腹時及び糖負荷後の過剩イン

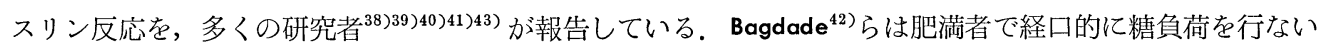
IRI を測定している. 肥満者は空腹時インスリン值が高く, 糖負荷後もインスリン反応が大きい. ての高イ ンスリン血症は, 肥満者の脂肪組織のインスリン感受性が低下しているため, 未梢組織のインスリン需要が 大きいためだろうとしている。しかしいずれも一つのインスリン測定法を用いているのみである. それ故肥 満において正常耐糖能を維持するのになぜ高インスリン血症が必要なのかの問に, insulin resistance 或い は insulin inhibitor なる言葉を用いているが, てれ自体明らかにしていない. そてで本研究では肥満と糖尿 病発症の原因をさぐるべく，インスリン三測定法, すなちちラット横隔膜法, ラット副辠脂法, 及び免疫学 的測法定を用いて，Table 1 による各群の ILA 及び IRI を同時に測定し，その結果を比較検討した. ての 三測定值の比較より肥満に insulin resistance を惹起するもの, 更に肥満の糖尿病に及ぼす影響について考察 した，測定結果によると正常者に比較して，非肥満糖尿病，すなわち肥満の影響をうけない糖尿病で DILA 
低く，FILA 高く，IRI やや高く頂伹遅㢟という型を示し，乙れを三法上糖尿病的傾向と判断した，肥満糖 尿病にはこの三法上の糖尿病的傾向が，さらに強くあらわれ，又未だ GTT 上異常を示さない肥満者にも 同様の，DILA 低く，FILA，IRI 高い傾向をみて，乙てに肥満者と糖尿病者の間には IRI が単に高いと いうのみならず，横隔膜法で低く副睪脂法で高いという共通点を見出したのである．先にのべた如く，横隔 膜法は単にインスリン測定法というに止まらず，in vitro ではあるが筋組織に対するインスリンの生物学的 活性の総和をうかがい知るものとしたのであり，副嶭脂法においても又同様である。さされば肥満者で正常な 而糖能を維持するのに高インスリン血症を要するのは，筋組織にはインスリン活性を阻害する物質があり (DILA-inhibitor), 脂肪組織にはその活性を阻害せず，又逆に増強する物質（FILA-activator）を想定せざ るを得ない，FILA-activator は肥満者の脂肪組織のインスリンえの感受性の低下している ${ }^{44)}$ ためインスリ ン以外の物質がその活性を代償的に増強しているのかもしれない．乙の DILA-inhibitor, FILA-activator なる物質は一つであるか又それ以上であるか不明であるが，てれが肥満に insulin resistance を惹起せしめ るものと推論した。 ての物質には, Vallance-Owen の Synalbumin Antagonist ${ }^{45}$ ) (TCA-Ethanol Extract ${ }^{20)}$ ), Antoniades $の$ Bound insulin ${ }^{46)}$, Randle らの $\mathrm{NEFA}^{14)}$, Segal ${ }^{47)}$ がまとめている各種ホルモンが考 えられる。

DILA inhibitor 亿は筋組織の糖代謝中, 細胞膜の所で blockするものと, 組織内で糖代謝を醰素レベル で block するものとが考光られる，前者にはSynalbumin Antagonist ${ }^{45)}$, 後者には主として NEFA ${ }^{14)}$ を 考えたい.

次に FILA は endogenous insulin と，てれのインスリン活性を増強するもの (FILA activator) と， 脂肪組織えのインスリン活性を抑制するものよりなつている。すなわち本論文では,

FILA = endogenous insulin +FILA activator +FILA inhibitor ${ }^{76)}-(1)$

で FILA は(1)式の三者の総和であると考光る，FILA activator には endogenous insulin の生物学的活 性を增強する物質と，インスリンでなくインスリン様活性を示す non insulin ILA よりなる即ち,

FILA activator $=$ insulin activator ${ }^{48}+$ non insulin ILA — (2)

(2)式の non-insulin ILA は Samaan ${ }^{49}$ のいう non suppreseble insulin にあたるかもしれないが本研究 では主として諸ホルモンの影響を推定している.

成長ホルモンが FILA に in vitro で影響を与えるが ${ }^{50)}$, 肥満者では成長ホルモン濃度は高くない で，乙れを無視出来る。副㹂皮質ホルモンは，脂肪組織の glucose uptake を抑制 ${ }^{52}$ するのでての場合除外 出来る。グルカゴンは in vitro で脂肪組織の糖代謝を促進し ${ }^{533}$, FILA に影響を与えるものの一つであ り, しかもForsham らの報告 ${ }^{54}$ より, 肥満者におけるグルカゴンの insulogenic property の增強をみてい るので, FILA activatorなる概念より見て注目すべきものかもしれない. しかし $\mathrm{C}^{14}$-1-glucose より $\mathrm{C}^{14} \mathrm{O}_{2}$ えの産生を指標とする FILA では諸ホルモンの影響は著しく減弱されるとの報告 ${ }^{55}$ もある,

本研究の FILA は脂肪組織の $\mathrm{C}^{14}$-1-glucose より $\mathrm{C}^{14} \mathrm{O}_{2}$ えの産生でみているので, endogenous insulin の活性をそれ以上に高かめる FILA-activator は，多分解糖系の pentose cycle (Warburg dickens pathway）の促進 ${ }^{56)}$ を意味し，ての cycle より産生される，NADPH は脂肪酸の合成を促進するかもしれない 77)。但し血中 NEFA が増加している状態では, 脂肪酸の合成は阻害 ${ }^{57}$ されているとの報告もあるので, 脂 肪酸合成より $\alpha$-glycerophosphate の増量までを推定して, てれが中性脂肪の産生, 蓄積を促し, 肥満を惹 起するものと考光てよい. FILA-activator にも Synalbumin Antagonist 及び, NEFA が考えられる.

Vallance-Owen の Synalbumin Antagonist ${ }^{58)}$ は糖尿病発症と遺伝的関係をユニークに結びつけている. 吉田は Synalbumin Antagonist は DILA に inhibitor として, FILA には activator として働くと報 告しているが ${ }^{20)}$ ，糖尿病的遺伝負荷のない肥満には Synalbumin Antagonism が弱いと ${ }^{5960)}$ の報告がある. 故に本研究の糖尿病的素因のない肥满者における DILA-Antagonist としての意義は少ない.

Antoniades ${ }^{46)} の$ bound insulin は FILA-activator としての報告をみていない.

次に Randle ${ }^{61)}$ の “glucose fatty acid cycle” なる概念によると，笳や脂肪組織において糖と脂肪酸代謝 
とは逆の関係にある。すなわち糖とインスリンは中性脂肪から逰離脂肪酸の放出を抑制し，脂肪酸の酸化は 解糖や糖の酸化，それに対するインスリン作用を抑制する。脂肜酸の增加は insulin insensitivity を筋組 織におてし，インスリンの糖の膜転送や, hexokinase, phosphofructkinase, pyrvatekinase, pyrvate dehydrogenase の活性を減弱させる。故に肥満者のILA に影響を及ぼすものに NEFAの可能性か浱い。そて で肥満者で NEFA がいかなる状態であるのかを糖負荷により観察した，本研究において，肥満者及び糖尿 病肥満者では，NEFA 值が正常者に比べて空腹時高く，負荷後下降が遅延し障害されていた，同様の結果 を Covilain ${ }^{65}$ 弓とO Opie ${ }^{66)}$ らも空腹時 NEFA 值で報告し, Randle ${ }^{61)}$ は，肥满者及び糖尿病者に糖負荷後 の NEFA の反応性の低下と遅延を強調している，肥満者には高インスリン血症と高 NEFA 血症が併存し， こてにどうしても insulin resistance の存在を考光ねばならない。そてで肥満者と肥満糖尿病者共通の DILA-antagonist, FILA-activator として NEFA を考えた。 in vivo における NEFA の高値が糖尿病的 傾向或いは耐糖能低下をもたらす実験が Nestle ${ }^{62)}$ らによつてなされている. Nestle は正常人にノルエピネ フリンを注射し, 血中 NEFA を増加させ, 静注したブドウ 糖除去率の低下より耐糖能の障害をのべ, Randle $^{63)}$ は，糖尿病と低糖質食の正常者に糖負荷をおてない，耐糖能の低下している両者に NEFA 高值 をみている，又 Schalch ${ }^{64)}$ は脂肪食投与後へパリン静注により NEFA を上昇させ，その後糖負荷を行ない 糖尿病的傾向を示した。 in vivo 亿おいて高 NEFA 值か渜糖能を低下させる事実と，本研究における， NEFA レベルの高い肥満の示した，三法測定上の糖尿病的傾向といかに結びつくかを家鬼に高脂肪食を与 え，肥満にして検討した。肥満家鬼は高 NEFA 值を示し，ほほ人の肥満と三測定法上同傾向を示し，肥満 の糖尿病的傾向の原因を NEFA 高値とする考光を支持した。

in vitro 亿わいて NEFA が DILA を抑制する事実 ${ }^{67) 68)}$ を Garland ${ }^{69)}$ はラッテの心臟と横隔膜を用いて, fatty acid を加え, Bowman ${ }^{70)}$ はラッテ心に, palmitate, oleate, linoleat を灌流して得ている, 又 FILA を促進する事は Leboeuf ${ }^{71)}$ らにより報告されている。本研究ではての in vitro の実験が， incubate 液中 飞直接 fatty acid を加えているのをいささか非生理的であると考光，より生理的に NEFA 高值の被検液 を得るために，高脂肪食投与70日時の肥満家鬼にヘパリンを静注し，血糖，IRI が不変で NEFA 高値であ る血清を得た。吉田 ${ }^{20)}$ はへパリンを in vitro で添加した時 FILA，IRI は影響なく DILA は高くなつた と報告している。乙の血清ではそ机飞もかかわらず，DILA 低值を，FILA 高值を得たので，確かにNEFA 高値が， DILA inhibitor, FILA activator となり, 三測定法上糖尿病的傾向の原因となると結論した。

以上の考察より肥满者が正常なる而糖能を維持するため何故高インスリン血症をもつて代償せねばならな いかは，恐らく肥満者に，insulin resistance がありその一因を高 NEFA 值がになつていると考えた。高 NEFA 值は筋組織えのインスリン活性を低下せしめ, その代償として過剩に分泌されたインスリンとその活 性をさらに高める因子が脂肪組織に lipogenesis 亿働き，更に肥満に導くのであろう。そして NEFA は insulin resistance を介して, 過剩のインスリン分泌を膵 $\beta$ 細胞に要求し ${ }^{72}$, 乙の状態が持続する時, 糖尿 病的遺伝素因をもつ脆弱な膵に対しては，代償不能，糖尿病状態を発症せしめるものと思われる。すなわち 三法によるインスリン上糖尿病的である本研究の肥満者は，糖代謝（GTT）は正常でありながら，脂質代

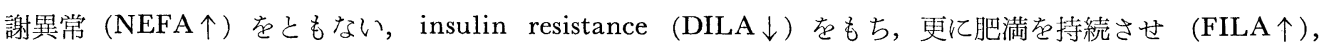
過剩のインスリン分泌（IRI个）を要求するという点で，糖尿病的ストレスとなり，糖尿病素因をもつもの には，糖尿病発症の誘因となり得ると結論した。

一方糖尿病の一症状として肥満がおこるとする ${ }^{31)}$ 人もいるが，肥満者で体重を減少するととにより耐糖能 を回復したとする Berkowitz ${ }^{73)}$ や Newburg ${ }^{3)}$ の報告や，又 Salan ${ }^{44)}$ の肥満者の脂肪組織を用いた実験で， 低下したインスリン感受性が体重減少によりその感受性を回復したとの報告もあり, 肥満が糖尿病によりお こるとする説も否定しないが，肥満は糖尿病的ストレスとなり可逆的なもので，糖尿病発症の誘因となると 考えたい.

肥满糖尿病はての様な糖尿病的ストレスに対し膵インスリン分泌の要求に代償しきれなくなり，IRI 高值 ながら糖尿病状態を発症したもので, 三法によるインスリン上非肥満糖尿病より肥満者に近い型を示した。 
少くとも肥満型糖尿病においては, NEFA 高值をともなつた, 脂質代謝異常が 糖代謝異常に先行していた と考えたい.

非肥満糖尿病は，IRI がもつともインスリンに特異的な測定法としても，糖負荷後のインスリン反応は， 少くとも本研究で Table 1 亿より分類された症例では, 正常者に比較して低下していない, 頂值が遅延し ているだけである．すなわち血清 $1 \mathrm{ml}$ 中のインスリンの絶対量は正常者と比較して減少していない，それ なのに耐糖能が著しく低下しているのは何故か，それはインスリンの生物学的活性に影響を与える物質があ るからで，てれの検索には三測定法を用いる必要性を再確認した。

しからば糖尿病的ストレスの因をなす NEFA 高值はいかにしておきるかが問題であろう. 糖尿病発症に 際し糖代謝異常に先行して, 脂質代謝異常が現われるとすれば，脂肪組織より NEFA を放出する因子，或 いは NEFA を含め Acyl Co $\mathrm{A}^{74)}$ 等の脂質中間代謝物質の増量が何故薏起されるかが今後の課題であろう. Recant $^{75)}$ らが糖尿病患者の血清中にシロネズミの脂肪組織から NEFA 放出を促進する物質が多い事を報 告しているが興味深い.

\section{総括}

1) 肥满と成人型糖尿病との間には, 統計学的にも, 臨床的にも何等かの関連を類推させる. 横隔膜, 副 䅸脂，免疫学的三測定法を用いて同一検体を同時に測定するととにより肥満と糖尿病の関係をみた。

2 ）三測定法よりみると糖負荷後正常者に比較して非肥満糖尿病は DILA 低く, FILA 高く, IRI 若干 高く頂值遅延なる糖尿病的傾向を示した。肥満糖尿病及び肥満でての傾向がさらに強く示された．

3 ）後二者で糖負荷後 NEFA の高值と下降の障害をみた，高脂肪食を投与した家鬼に肥満をもたらせた が，乙の血清は NEFA 值高く三法上人肥满と同様の傾向をみた。

4）インスリンの生物学的活性に及ぼす，NEFA の影響をみるため肥満家鬼にヘパリンを静注し，高 NEFA 血清を得た。乙の血清は DILA 低く, FILA 高い先の糖尿病的傾向を示し，NEFA 高值が肥满に 三測定法上糖尿病的傾向を与光たものと結論した。

5 ）乙れ等の結果より, 三測定法上糖尿病的傾向を示した肥満は, 糖代謝 (GTT) は正常でありながら,

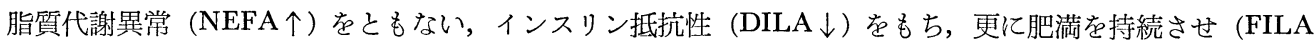
个), 過剩インスリン分泌 (IRI 个) を要求して, 糖尿病的ストレスとなる. 従つて糖尿病的素因をもつもの には，糖尿病発症の誘因となるであらう。

\section{結 語}

肥满者は横隔膜法で低值を，副梓脂法，免疫学的測定法で高值を示し三測定法上糖尿病的である。この一 因は高 NEFA 值による. 即ち肥満は糖尿病的ストレスとなり，糖尿病的素因のあるものには糖尿病発症の 誘因となる.

閐筆するにあたり，終始御懇䉆なる御指導，御校閲を賜わつた恩師吉田秀雄教授に深甚なる謝意を捧げ， 種々御教示頂いた奥村賢太郎講師に深謝の意を表します。尚, 本研究に御協力頂いた進藤岱三, 阿部信行両 学士並びに足立典夫, 筷屋昌文両学士に感謝致します。

\section{文献}

1) WILliAMS, R.H. : Textbook of Endocrinology, 3rd Ed. W.B. Saunders. Co., Philadelphia 609, (1962). $\quad$ 2) JOSLIN, E.P., DUbLiN, L.I., MARKS, H.H. : Amer. J. Med. sc. 192 : 9, (1936). 3) OGILVIE, R.F. : Quart. J. Med. $4: 345$, (1935). $\quad$ 4) MEDLEY, D.R.K. : Quart. J. Med., $34: 111$, (1965).

5) VALLANGE-OWEN, J. LILLEY, M.D. : Lancet, $1:$ 806, (1961). BEASER, S.B. : J.A.M.A., 199 : 990, (1967).

7) KARAM, J.H., GRODSKY, G.M. and 
FORSHAM, P.H. : Diabetes, $12: 197$, (1963). BERSON, S.A. : Ann. N.Y. Acad. Sci. 131 : 357, (1965).

8) YALOW, R., GLIGK, S.N., ROTH, J. and

Hosp. Bull., 66 : 232, (1939).

吉田秀雄 : 糖尿病, $2: 11$, (1959).

: Endocrinology, $46: 55$, (1950).
9) GEMMILL, G.L.: Johns Hopk.

12) RENOLD, A.E., A. MARBLE and D.W. FAWCETT

13) BERSON, S.A. and YALOW, R.S. : J. clin. Invest., $39: 1157,(1960)$.

14) RANDLE, P.J., HALES, C.N., GARLAND, P.B. and NEWSHOLME,

E.A. : Lancet, 1 : 785, (1963).

16）奥村賢太郎：日本内分泌学会雑誌, $35: 1564,(1960)$.

15) GUNNIGHAM, N.F. : J. Endocrin. 25 : 35, (1962). Amer. J. Cancer, 27 : 45, (1936).

18）馬場茂明, 他：日本内分泌学会雑誌, $35: 50$, (1959). 19) HAGEDORN, H.G., and JENSEN, B.N. : Biochem. Z. 135 : 46, (1923).

20) 吉田秀雄 :

日本内分泌学会雑誌, $44:$ (1968), 印刷中.

DAGENAIS, Y.M. : J. clin. Invest., 39 : 1487, (1960).
21) RENOLD, A.E., MARTIN, D.B. and

22) DITSGHUNEIT, H., GHANG-

SUAHN, PFEIFFER, M. and PFEIFFER, E.F. : Klin. Wschr., 37 : 1234, (1959).

HerberT, V., K. LAU, G.W. GOTtlief, S.J. BleiGHER : J. clin. End., 25 : 1375, (1965). 24) 吉田秀雄, 他 : 日本内分泌学会雑誌, $44: 181$, (1968).

25) DOLE, V.P. : J. clin. Invest., $35: 150$, (1956).

26）富川哲夫：日本内分泌学会雑誌， $42 ： 29$, (1966).

27）野田信顕 : 日本内分泌学会雑誌, $42: 29$, (1966). 28 ) MORSE, W.I., SIDOROV, J.J., SOELDNER, J.S. and DICKSON, R.C. : Metabolism $9: 666$, (1960).

29) SGHLEGHTER, P. \& ANNA MARIA VILLA. : Amer. J. clin. Nutri. $10: 433$, (1962).

30) NEWBURG, L.H., and CONN, J.W. : J.A.M.A. $112:$ 7, (1939). 31) FALUDI, G., BENDERSKY, G., and GERBER, P. : Diabetes, Supple. $17: 323$, (1968).

32) RABINOWITZ, D. and ZIERLER, K.L. : J. Clin. Invest. 41 : 2173, (1962). $\quad 33$ ) BORNSTEIN, J. and LAWRENGE, R.D. : Brit. Med. J. 2 : 1541, (1951). 34) VALLANCE-OWEN, J. : Lancet, $2: 583$, (1955). DEMPSTER, W.J. : Briti. Med. J. 1 : 1153, (1965). 35) SAMAAN, N., FRASER, R. and 36) DAWEKE, H., H. VAN LANDEGHEM, W. WINKELMANN, I. BAGH : Klin. Wschr., 4 : 190, (1965). BOTTERMANN, P., SCHWARZ, K. and KOPETZ, K. : Deut. Med. Wschr., 90 : 917, (1965). 38) MELANI, F., J. LAWEGKI, E.F. PFEIFFER : Diabetologia, $3: 422$, (1967). BUCHANAN, K.D. and McKIDDIE, M.T. : Diabetes, $16: 466$, (1967).

40) SELTZER, H.S., E.W. ALLEN, A.L. HERRON, JR., : J. clin. Invest. 46 : 323, (1967). 41) PERLEY, M.J., D.M. KIPNIS : J. clin. Invest., 46 : 1954, (1967).

42) BAGDADE, J.D., E.L. BIERMAN, D. PORTE : J. clin. Invest., 46 : 1549, (1967).

43) KREISBERG, R.A., BOSHELL, B.R., DIPLAGIDO, J., RODDAM, R.F. : New. Engl. J. Med., 276 : 314, (1967).

44) SALANS, L.B., J.L. KNITTLE, J. HIRSGH : J. clin. Invest. 46 : 1112, (1967).

45) VALLANCEOWEN, J. : Diabetes. $13: 241$, (1964).

46) ANTONIADES. H.N. and GERSHOFF, S.N. : Diabetes $15: 655$, (1966). 47) SEGAL, B.M. : Metabolism, $13: 753$, (1964). POWER, L., C. DUCAS and J.W. CONN : Diabetes $14: 10$, (1965).

49) SAMAAN, N.A., DEMPSTER, W.J., FRASER, R., PLEASE, N.W., STILlMAN, D. : J. Endocrin., 24 : 263, (1962). 50) GOODMAN, H.M. : Endocrin., $76: 216$, (1965). $\quad$ 51) BEGK, P., DAVID, M. KIPNIS : J. Lab. \& clin. Med. $64:$ 654, (1964). 52) WEINGES, K.F. and G. LOFFLER : Klin. Wschr., $42:$ 502, (1964). 53) HAGEN, J.H. : J. Biol. Chem. $236: 1023$, (1961). BENEDETTI, A., R.G. SIMPSON, G.M. GRODSKY, P.H. FORSHAM : Diabetes, 16 : 666, (1967). 55) SHEPS, M.G., NIGKERSON, R.J., DAGENAIS, Y.M., STEINKE, J., MARTIN, D.B. and RENOLD, A.E. : J. clin. Invest., 39 : 1449, (1960).

56) PAWN, G.L.S. : Proc. Poy. Soc. Med., 
59 : 1275, (1966).

57) MASORO, E.J. : J. Lipid Res., 3 : 149, (1962).

58) VALLANGE-

OWEN, J. : Diabetes, 13 : 241, (1964).

59) VALLANGE-OWEN, J. : On the Nature and

Treatment of Diabetes, (1965), 393, Netherland by Mouton \& Co., The Hague.

60. 奥村賢太

郎: 糖尿病学の進歩, 68, 診断之治療社, (1968). 印刷中

61) RANDLE, P.J., P.B. GARLAND,

E.A. NEWSHOLME, G.N. HALES : Ann. N.Y. Acad. Sci., 131 : 324, (1965).

62) NESTEL,

P.J., GARROLL, K.F., SILVERSTEIN, M.S. : Lancet, 2 : 115, (1964).

63) HALES, G.N.,

P.J. RANDLE : Lancet, $1: 790$, (1963).

64) SCHALGH, D.S., KIPNIS, D.M. : J. clin. Invest., $44: 2010$, (1965).

65) CORVILAIN, J., LOEB, H. : Lancet, $1: 534$, (1961).

66)

OPIE, L.H., and WALFISH, P.G. : New. England J. Med. 268 : 757, (1963).

67) SHIPP, J.G., OPIE, L.H., GHALLONER, DAVID : Nature, Lodd, 189 : 1018, (1961).

68) BÜHRING,

H. : Biochem. J., 89 : 32p, (1963).

69) GARLAND, P.B., E.A. NEWSHOLME, P.J. RANDLE

: Nature, 195 : 381, (1962).

70) BOWMAN, R.H. : Biochem. J. 84 : 14p, (1962).

71)

LEBOEUF, B., CAHILL, G.F. JR. : J. biol. chem., 236 : 41, (1961).

72) KENNEDY, G.C., R.A. PARKER : Lancet, 2 : 981, (1963).

73) BERKOWITZ, D. : J.A.M.A., $187: 399$, (1964).

74) TUBBS, P.K., P.B. GARLAND : Biochem. J., 93 : 550, (1964).

75) REGANT, L.L.,

ALP, H., KOGH, M.J. EGGEMAN : Lancet, 2 : 614, (1963).

76) POWER, L., S. JOHN :

Diabetes, $16: 483$, (1967).

77) SIPERSTEIN, M. \& FAGGAN, V.M. : J. clin. Invest., 37 :

1196, (1958). 